\title{
The Letters of Lord Burghley, William Cecil, to his Son Sir Robert Cecil, 1593-1598
}

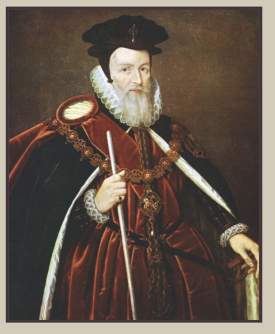

William Acres teaches Comparative Religion and History in the Faculty of Theology at Huron University College, London, Canada. He has recently completed Exploring Religion: A Reader (Oxford, 2014). He has won numerous teaching and research awards and given extensive interviews on radio. He has also worked on materials relating to the Truth and Reconciliation Commission in Canada, using pedagogy and historical research for inter-cultural awareness.

The 128 letters of William Cecil, Lord Burghley, to his son Sir Robert Cecil in Cambridge University Library, Manuscript Ee.3.56, are the largest collection of papers showing the close direction and counsel he gave his son in seeking and obtaining the office of Principal Secretary, 1593-1598. The materials concentrate on the task of receiving and crafting a wide and large array of papers on behalf of Queen Elizabeth I and her Privy Council; finance, administration, foreign policy, and religion figure prominently, as does the shift from continental war to Ireland. These letters also reveal the intimate relationship between the father and son;

Burghley's care for his family, his thoughts of death, and a unique record of illness and old age are framed by his political and spiritual anxieties for the future of the Queen and her realms.

Cover Illustration: William Cecil, 1st Baron Burghley. Print published in Parliament Past and Present by Arnold Wright and Philip Smith (London, c. 1905). Original painting by Marc Gheeradts. (Photo: The Print Collector/Getty Images.) SOCIETY 